\title{
A mentorálásban rejlő lehetőségek és kihívások
}

\author{
Molnár Krisztina \\ Szinyei Merse Pál Gimnázium intézményvezető-helyettese \\ Szinyei Merse Pál Gimnázium \\ molnar.krisztina@szinyeigimibp.hu
}

DOI: 10.37205/TEL-hun.2019.3-4.09

A Budapest VI. kerületi Szinyei Merse Pál Gimnázium már több évtizede fogad hallgatókat rövid, illetve hosszú tanítási gyakorlatra. Kapcsolatunk először informálisan indult az ELTE-vel, amikor felkérték egyik kollégánkat, hogy egy biológia-kémia szakos hallgatót mentoráljon. A kapcsolat később hivatalossá vált, sőt kapcsolatrendszerünk kiszélesedett, és ma már a Károli Gáspár Református Egyetemmel és a Pázmány Péter Katolikus Egyetemmel is együttmúködünk partnerintézményként hallgatóik iskolai gyakorlatainak lebonyolításában.

Az egyetemekkel való szoros együttmüködést az iskolavezetés fontosnak tartja egyfelől, mert sok diákunk tanul tovább ezekben az intézményekben, másfelől, mert felelősséget érzünk a következő tanárgeneráció minél teljesebb felkészítése, pályaszocializációja, pályán tartása iránt. Nem titkolt szándékunk, hogy saját iskolánk tanárutánpótlását legalább részben fiatal pályakezdőkkel oldjuk meg. Így a tanárjelöltekkel való foglalkozás összefonódott jövőbeni kollégáink kiválasztásával, felkészítésével, és a mentorálás mára iskolai életünk meghatározó elemévé vált. Az alábbiakban szemléletünk és gyakorlatunk néhány alapvető elemét mutatom be, továbbá kitérek a nehézségekre, amelyekkel szembesülünk, és amelyekre megoldást keresünk.

A mentorálást, a tanárjelöltek megismertetését az iskolai élet valóságával nem formális feladatnak - körbevezetésnek, tapasztalatmegosztásnak - tekintjük, hanem a tanári szemlélet, szerep és tevékenység színvonalát meghatározó lehetőségként. Személyre szabott folyamatként értelmezzük, amelynek során a tanárjelöltet a személyiségével harmonizáló szemlélet és gyakorlat kialakításában szükséges támogatni. Ennek szem előtt tartását és az együttműködés tartalmas, fejlesztő voltát azzal is igyekszünk biztosítani, hogy a mentorálás koordinálása intézményvezető-helyettesi szinten és hatáskörben valósul meg, és a felelős intézményvezetőhelyettes maga is mentortanári szakiránnyal rendelkező mesterpedagógus. 
650 nappali tagozatos tanulói és 65 fős tantestületi létszámú iskolánk félévente átlagosan 10-12 tanárszakos hallgatót fogad különböző gyakorlatok teljesítésére. A mentorálási tevékenységre a kollégák nyitottak voltak, bár az első esetekben még sem a feladat jelentette megterhelésre, sem a szakmai kihívásokra nem voltak teljesen felkészülve. Az iskola vezetősége kezdetben a megfelelő szakértelemmel és kiváló emberi kvalitásokkal rendelkező kollégákat kérte fel a feladatra. A gyakorló hallgatók létszámának növekedésével a szakszerű mentorálás biztosításához szükség volt arra, hogy a tantestület mentorálásba bekapcsolódó tagjai mentortanári végzettséget szerezzenek. Jelenleg négy mentortanári szakiránnyal rendelkező mestertanárunk van, továbbá a szakvizsgázott pedagógusok közül is több mint tíz kolléga mentortanári végzettséggel rendelkezik. A mentorálásba folyamatosan kapcsolódnak be újabb tanárok, és folyamatosan szereznek gyakorlatvezető mentortanár szakirányú szakvizsgát. Tanulmányaikat az intézmény például vizsgára készüléskor szabadnappal támogatja. Iskolánk profiljának, értékrendjének megfelelően a hallgatókkal való foglalkozás a kollégák számára vonzó feladattá vált, és a szakmai elismerés mellett - az egyetemekkel megkötött szerződéseknek megfelelően több-kevesebb - anyagi elismerésben is részesülnek.

Mentorálási szemléletünk és bánásmódunk alapja, hogy a tanárjelölteket az első perctől fogva partnernek és a tantestület tagjainak tekintjük. Ezért a hozzánk érkező hallgatókat az intézmény vezetősége fogadja, az iskola bemutatását, bejárását is a vezetőség egyik tagja vezeti. A támogatásukra felkért mentortanárral ezt követően ismerkednek meg. A hallgatók már augusztusban, az alakuló értekezleten részt vehetnek, ahol bemutatjuk őket, illetve bemutatkoznak a tanári karnak. A tantestület életébe való bekapcsolódást segíti, hogy a mentortanárok hozzájárulásával iskolai programokba vonjuk be a tanárjelölteket: részt vesznek a gólyavacsorán, lehetőséget kapnak, hogy velünk táncoljanak a szalagavatón a tanártáncban, a halloween partynak, a farsangnak maguk is aktív résztvevői. A tanárjelölt nem kizárólag egy adott mentortanár hallgatója, hanem a tantestület tagja. A tantestület tagjai örömmel veszik, hogy olyan fiatalok vannak közöttük, akik maguk is tanárok akarnak lenni, támogatásukba szívesen bekapcsolódnak.

A tanárjelöltek között keresve a lehetséges munkatársakat, nem csak az egyetemek hivatalos elvárásai szerint kísérjük figyelemmel a hallgatókat a gyakorlati idő során. A gyakorlatvezető mentortanár és az adott munkaközösség véleményét kikérve figyelhetünk fel azokra, akikből később a Szinyeiben tanító tanár válhat. Szívesebben dolgozunk olyan új kollégával, akit már hallgatóként megismertünk, 
és az intézmény hagyományai, értékei, szabályai szerint szocializálódott, hiszen ők már beilleszkedtek, fél szavakból is megértjük egymást, és néha az idősebbeket meghazudtoló az iskolához való kötődésük. Jelenleg is több ilyen fiatal kollegánk van.

Aktuális dilemmánk, hogy miközben intézményi szinten komoly erőforrásokat mozgósítunk annak érdekében, hogy a tanárjelöltek mentorálása, felkészítése magas színvonalú legyen - és a visszajelzések szerint ezt el is érjük -, a tehetséges fiatalok pályán tartásában kudarcokkal is szembesülünk. Példa lehet erre az a pályakezdő tanár kollégánk, aki nálunk gyakorolt, majd iskolánkban kezdett el dolgozni, végül mégis elhagyta a tanári pályát. Ennek oka az volt, hogy aránytalanul nagynak érezte a munkaterheket, a felelősséget (a kötelező óraszám mellett portfóliót írni, rendszeresen helyettesíteni, iskolai programokon részt venni, osztályfőnök-helyettesként helytállni), és szerénynek a fizetést, amelyből nem tudta lakhatási és megélhetési költségeit finanszírozni a szülei támogatása nélkül. Számításai szerint hetente több mint ötven (!) órát dolgozott 140 ezer forintért. Jelen pillanatban is két kezdő kolléga fontolgatja a pályaelhagyást hasonló okokból. Komoly veszteség olyan tehetséges tanárok távozása, akik mind a pálya, mind az iskola iránt elkötelezettek. Hangsúlyozom, hogy nem másik intézménybe mennek, hanem a tanári hivatást adják fel valami jövedelmezőbbért! Mit tehetnek a mentortanárok, intézményvezetők, ha a pedagóguspálya a kezdők számára nem biztosít megélhetést?

Nehézséget jelent, hogy a partnerintézményi mentortanárok teljes óraszámban tanítanak, kevés az idejük a felkészülésre, a hallgatói órák látogatására, és az egyéb mentorálási feladatokat a szabadidejük terhére oldják meg, mert így tudnak saját igényeinek, elvárásaiknak megfelelni. A jelenlegi túlterhelés viszont a kiégés veszélyét erősítheti. Milyen modell válhat a kiégett mentortanárokból?

A nehézségek és a pályaelhagyások kudarca személyesen is megérint, és felmerül bennem a felelősség kérdése. Mit tehetnénk a mentortanárok lelki egészségének megőrzéséért? Mit tehettem volna mint mentortanár, mint intézményvezető-helyettes, hogy tehetséges kollégákat ne veszítsünk el? Hogyan tartsam ébren a lelkesedést magamban és mentortanár társaimban a folytatáshoz?

Az intézmények és a mentortanárok befektetett munkája akkor térülhet meg, ha munkájukat elismerik. Itt nem csak az anyagi ellentételezésre gondolok, bár az is fontos. Munkánk minőségét jelentősen növelné és a mentortanárok kiegyensú- 
lyozottságához jelentősen hozzájárulna, ha partnerintézményként is megkaphatnánk a gyakorlóiskolák számára a törvény által biztosított órakedvezményeket.

Amíg a külső körülmények vonzóvá válnak, addig a sikereinkre kell támaszkodunk, abból töltődünk fel. Mit jelent a siker mentortanáraink számára? Amikor mentoráltja meghívja a diplomaosztójára mint egyedüli külsőst a közvetlen családtagjai mellé. Amikor a pálya annyi szépségével sikerül megismertetni a tanárjelöltet, hogy a nehézségek ellenére marad. Amikor már a portfólióját írja a Pedagógus II. kategóriába kerüléshez, és a mentorától kér szakmai véleményt, támogatást. Amikor már ő is felkérést kap mentorálásra, és mentorát kéri fel, hogy útmutatást adjon. 